\title{
Culture-independent characterisation of human faecal flora using rRNA-targeted hybridisation probes
}

\author{
Joël Doré*, Geneviève Gramet, Isabelle Goderel, \\ Philippe Pochart \\ Institut national de la recherche agronomique, Domaine de Vilvert, \\ 78352 Jouy-en-Josas cedex, France
}

\begin{abstract}
Comparison of cultural and microscopic counts indicates that a significant fraction of human faecal flora is nonculturable. To characterise human faecal flora using quantitative dot-blot hybridisation, a set of ten ribosomal ribonucleic acid (rRNA)-targeted oligonucleotide probes were used to quantify rRNA abundance of different microbial groups within total RNA from faeces of ten individuals. The three domains and major groups of the domain bacteria were investigated. Cultural counts were compared with rRNA relative abundance for total Bacteroides, Bifidobacterium and Escherichia coli. Bacterial rRNA represented $78.2 \pm 4.3 \%$ (range 59-94) of total rRNA. The archaeal and eucaryal rRNAs only showed a minor contribution to total rRNA $(0.28$ and $2.02 \%$, respectively), the added contribution of all three domains accounting for $80.5 \pm 4.5 \%$ (range $61-100$ ) of total rRNA. Additive probes targeting high G + C Gram-positives (HGC) and other bacteria (NHGC) hybridised with 1.4 and $80.6 \%$ of bacterial rRNA, respectively. Total Bacteroides and enterics-group rRNAs accounted for $35.5 \pm 4.5 \%$ and $2.7 \pm 0.7 \%$ of bacterial rRNA, respectively. These results suggested a very significant contribution of low $\mathrm{G}+\mathrm{C}$ Gram-positives (LGC) to total bacteria. Assuming that Bacteroides and enterics were the major Gram-negatives present, LGC could be calculated to account for 47 to $67 \%$ of bacterial rRNA. Partial probing of LGC accounted for $24 \pm 5.5 \%$ of bacterial rRNA. Cultural counts were more variable between individual faecal samples than were rRNA relative abundances for all three groups enumerated. Average counts of Bacteroides and Bifidobacterium, expressed as percent of total anaerobes, were two-fold higher than the corresponding rRNA indices, indicating a systematic overestimation of these groups. This could be due to an underestimation of total anaerobes. Our results indicate that culture-based techniques introduce a bias in the appreciation of the biodiversity of the human gut flora. LGC are apparently more susceptible to cultural underestimation. Their diversity as well as their functional contribution to the gut ecosystem may therefore need reconsideration. A complete molecular inventory of human faecal flora, currently underway in our laboratory, and probebased technologies will certainly help to this end. (c) Inra/Elsevier, Paris
\end{abstract} molecular ecology / microbial diversity / rRNA / hybridisation / faecal flora

\footnotetext{
* Correspondence and reprints
} 
Résumé - Caractérisation moléculaire de la microflore digestive humaine par hybridation quantitative a l'aide de sondes ciblant les ARNr. La comparaison des dénombrements au microscope ou par culture anaérobie de la flore fécale humaine indique l'existence d'une fraction non-cultivable importante. Nous avons utilisé l'hybridation quantitative en dot-blot pour caractériser la structure et la diversité de la flore fécale humaine par une méthode indépendante de la culture. Un ensemble de dix sondes ciblant les ARNr a permis la quantification relative des ARNr de divers groupes microbiens dans les selles de dix volontaires sains. Les trois domaines primordiaux et les groupes majeurs du domaine Bacteria ont été étudiés. Le dénombrement par culture de Bacteroides, Bifidobacterium et Escherichia coli a été comparé avec la quantification relative des ARNr correspondants. L'ARNr du domaine Bacteria a représenté 78,2 $\pm 4,3 \%$ [extrêmes 59-94] de l'ARNr total. Les ARNr des domaines Archaea et Eucarya n'ont présenté qu'une contribution minime à l'ARNr total $(0,28$ et $2,02 \%$, respectivement), portant la contribution des trois domaines à $80,5 \pm 4,5 \%$ [61-100] de l'ARNr total. Deux sondes additives ciblant les Gram positifs à haut $(\mathrm{G}+\mathrm{C}) \%(\mathrm{HGC})$ et les autres bactéries (NHGC) ont reconnu 1,4 et $80,6 \%$ de l'ARNr bactérien, respectivement. Les $\mathrm{ARNr}$ des Bacteroides et du groupe des entériques ont représenté $35,5 \pm 4,5 \%$ et $2,7 \pm 0,7 \%$ de l'ARNr bactérien, respectivement. Ces résultats suggéraient une contribution importante des bactéries Gram positives à bas $(\mathrm{G}+\mathrm{C}) \%(\mathrm{LGC})$ dans la flore totale. Si Bacteroides et les entériques sont bien les Gram négatifs dominants de la flore, la contribution attendue des LGC est de 47 à $67 \%$ de l'ARNr bactérien. Une sonde reconnaissant partiellement le groupe LGC a donné une contribution s'élevant à $24 \pm 5,5 \%$ de l'ARNr bactérien. Les dénombrements par culture anaérobie se sont montré plus variables entre individus que ne l'étaient les quantifications relatives d'ARNr pour les trois groupes microbiens concernés. Les moyennes de dénombrements de Bacteroides et Bifidobacterium, exprimées en pourcent de la flore totale, étaient supérieures d'un facteur 2 aux quantités relatives d'ARNr correspondantes, suggérant une surestimation systématique de ces groupes par la culture. Cela pourrait être dû à une sous-estimation de la flore totale. Nos résultats indiquent que la culture anaérobie biaise la reconnaissance de la biodiversité réelle de l'écosystème digestif humain. Les LGC sont plus sensibles à une sous-estimation par la culture. Leur diversité et leur contribution fonctionnelle à l'écosystème digestif devront être réévaluées. L'inventaire moléculaire complet d'une flore fécale humaine, en cours dans notre laboratoire, va permettre d'avancer dans ce sens et de compléter le panel actuel de sondes d'hybridation. (c) Inra/Elsevier, Paris

écologie moléculaire / diversité microbienne / ARNr / hybridation / flore fécale humaine

\section{INTRODUCTION}

Human colonic microflora is composed of more than $10^{11}$ microbial cells per gram of intestinal contents, belonging to as many as 400 different species (Conway, 1995). Their recognition has been possible so far due to culture-based enumeration and identification under strict anaerobic conditions. Nevertheless, culture-based techniques introduce a bias illustrated by the recognition of a fraction of not yet cultured components within this ecosystem, representing 10 to $90 \%$ of the total anaerobic flora, according to various studies (Moore and Holdeman, 1974; Finegold et al., 1983; Langendijk et al., 1995; Wilson and Blitchington, 1996).

Modern molecular techniques based on sequence comparisons of nucleic acids represent a powerful tool for a culture-independent characterisation of the microbial structure of complex ecosystems. In this respect, ribosomal 
ribonucleic acid (rRNA)-based methods have proven most appropriate (Pace et al., 1985; Ward, 1989; Sayler and Layton, 1990; Stahl and Amann, 1991; Ward et al., 1992; Olsen and Woese, 1993; Stahl, 1993a, b; Mackie and Doré, 1995). The highly conserved regions of rRNA molecules can serve as target sequences for universal or domain probes (discriminating between the domains Archaea, Bacteria and Eucarya, sensu Woese et al., 1990). The intermediate and more variable regions are appropriate for the design of genus-, species- and, sometimes, strain-specific hybridisation probes.

In the present study, we used rRNA-based quantitative dot-blot hybridisation for the characterisation of the community structure of human faecal microflora. The three domains and major groups of the domain bacteria were investigated. Whenever possible, cultural counts were compared with rRNA relative abundance.

\section{MATERIALS AND METHODS}

\subsection{Total faecal RNA extractions}

Human faecal samples ( $0.2 \mathrm{~g}$ in $2.2 \mathrm{~mL}$ screw-cap tube) were initially subjected to direct phenol extraction with mechanical disruption (Mini-beadbeater, Biospec Products, Bartlesville, OK, USA) using $0.2 \mathrm{~g}$ zirconium beads as previously described (Stahl et al., 1988; Doré et al., 1998). Nucleic acid extracts were quantified spectrophotometrically.

\subsection{Probes and labelling}

Synthetic high-performance liquid chromatography (HPLC) purified oligonucleotide probes (Appligene, Illkirch, France) were $5^{\prime}$-end labelled with ${ }^{32} \mathrm{P}$ by using polynucleotide kinase (Gibco-BRL, Eragny, France) and $\left[\gamma^{32} \mathrm{P}\right] \mathrm{ATP}$ (specific activity of $\geqslant 5000 \mathrm{Ci} / \mathrm{mmol}$; Amersham, Les Ulis, France). The efficiency of labelling, assessed by thin-layer chromatography using polyethyleneimine cellulose plates and $0.5 \mathrm{M}$ ammonium carbonate as mobile phase, was always above $75 \%$.

\subsection{Total RNA dot-blot hybridisation}

Samples of 0.5 to $500 \mathrm{ng}$ total RNA from control pure cultures and 0.1 to $1 \mu \mathrm{g}$ total RNA from frozen faecal samples were vacuum-blotted on Nytran $\mathrm{N}$ membranes using the Minifold I (Schleicher and Schuell). Hybridisations were performed as previously described (Raskin et al., 1994; Doré et al., 1998). The probes used are shown in table I. Quantification of hybridisation signals on dotblots involved radioimaging using the Instant Imager (Packard Instrument). Figure 1 illustrates the results of parallel hybridisation on similar total faecal RNA dilutions.

\subsection{Units}

All quantitative rRNA measurements were standardised using rRNA extracts from pure cultures of Bifidobacterium bifidum (authors' collection), 


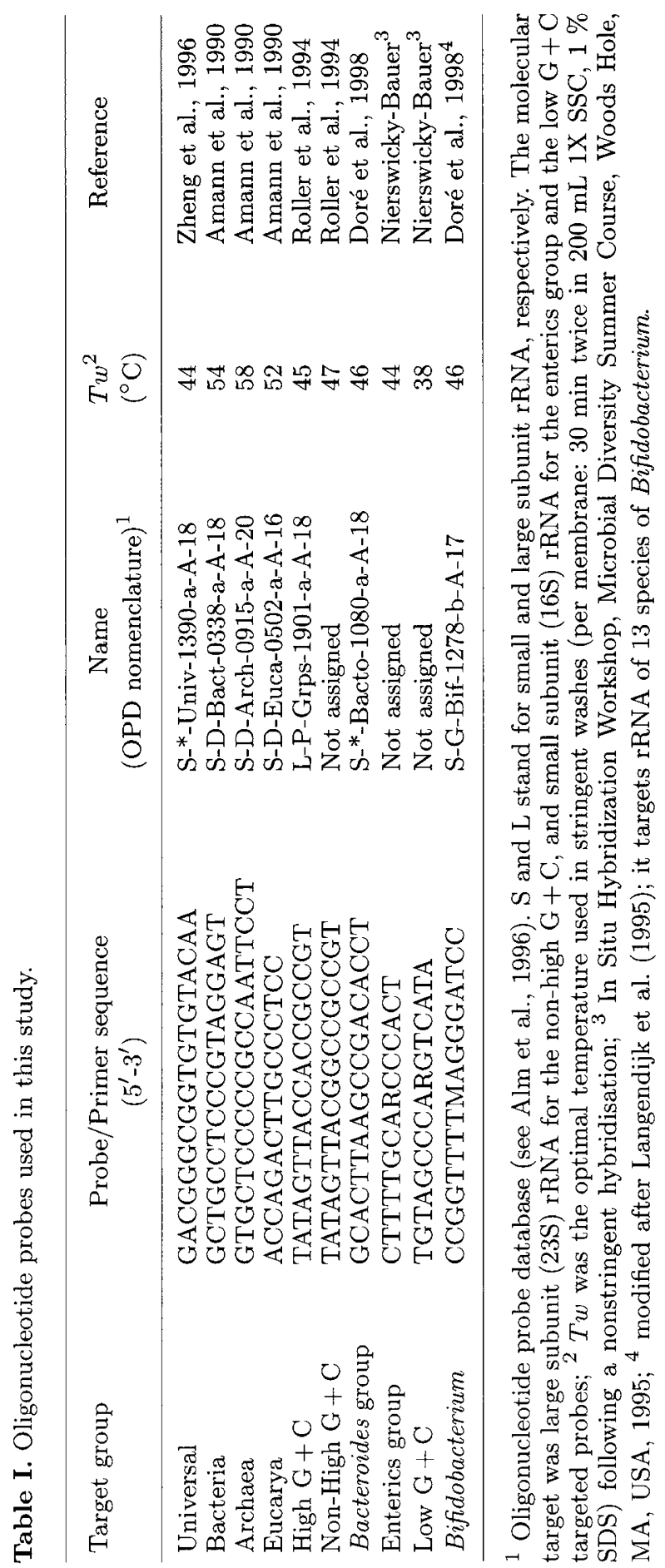



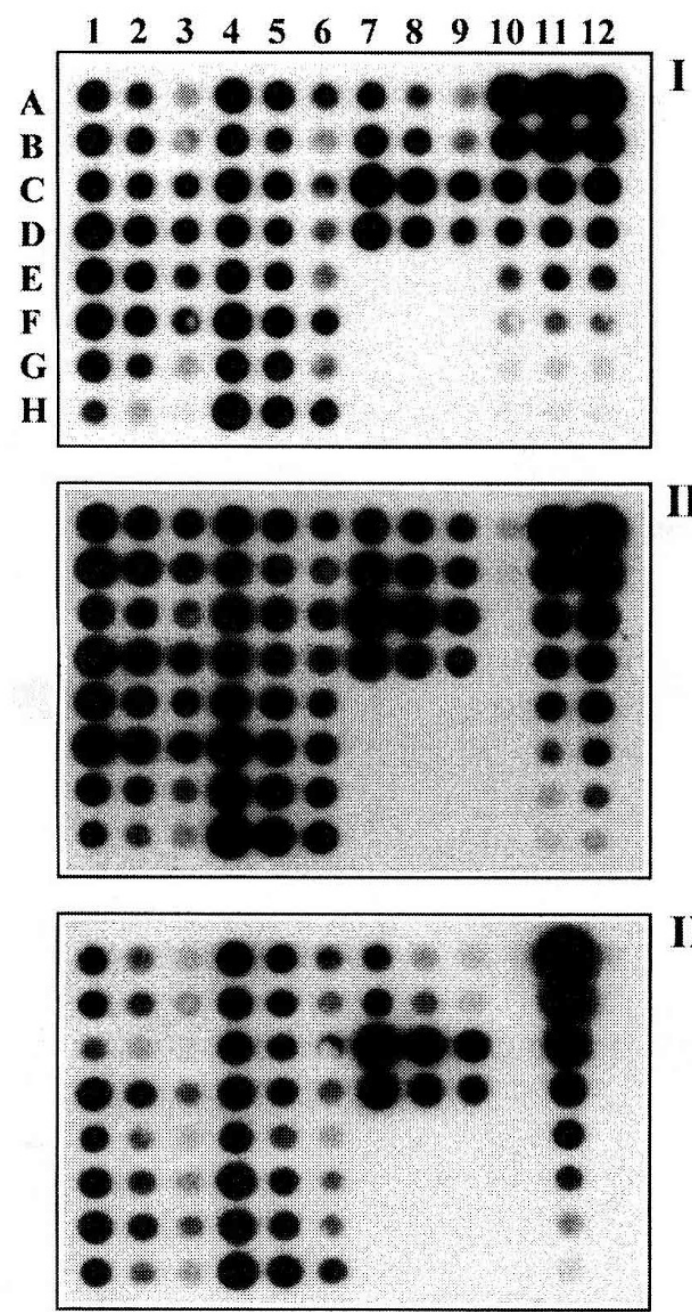

III

Figure 1. Membrane-based quantitative dot-blot hybridisation analysis of human faecal microflora. Total RNA extracts from human faecal samples were denatured and dotted onto nylon membranes in duplicate series of three two-fold dilutions, and hybridised with $32 \mathrm{P}$-labelled probes. The autoradiograms shown as examples are for hybridisation using the Bacteria domain probe (I), the non-high $\mathrm{G}+\mathrm{C}$ Grampositives group-specific probe (II) and the Bacteroides-Porphyromonas-Prevotella cluster probe (III; see table I for probe sequence). The arrangement of the faecal RNA extracts on the membranes was as follows (dot numbers): (A1-H1, A4-H4 and A7-D7) undiluted RNA extracts containing 0.1 to $1 \mu \mathrm{g}$ total RNA; (A2-H2, A5-H5 and A8D8) corresponding two-fold dilutions and (A3-H3, A6-H6 and A9-D9) corresponding four-fold dilutions. Columns 10,11 and 12 contained total RNA from the control organisms Bifidobacterium sp. (authors' collection), Bacteroides vulgatus (ATCC 8482) and Escherichia coli (Boehringer Mannheim 16S and 23S rRNA), respectively, in two-fold dilutions ranging from 3 to $400 \mathrm{ng}$ RNA. Other dots were RNA-free buffer controls (E7-H9). Scans were digitised from the Instant Imager (Packard Instrument S.A., Rungis, France) direct readings. 
Bacteroides vulgatus (ATCC 8482), E. coli (Boehringer Mannheim rRNA standards), Saccharomyces cerevisiae (authors' collection) and Methanobrevibacter smithii (ATCC 35061). Results are expressed as percent of total or bacterial rRNA, as measured using a universal or Bacteria domain probe and given as mean \pm standard error of the mean of triplicate RNA dilutions for each faecal extract.

\subsection{Microbial enumerations}

For the enumeration of total Bacteroides, dilutions of human faecal samples were plated using brain-heart infusion and exposed to air for $1 \mathrm{~h}$ to preselect for non-extremely oxygen-sensitive microorganisms, prior to incubation under strict anaerobic conditions at $37^{\circ} \mathrm{C}$ for $48 \mathrm{~h}$ (Corthier et al., 1996). Colonies were transferred onto Nytran-Plus membranes (Schleicher and Schuell, Ecquevilly, France) following the manufacturer's recommendations. Colony hybridisation was used for the enumeration of colonies belonging to the target group using the Bacteroides-specific oligonucleotide probe (Doré et al., 1998). Bifidobacterium spp. and $E$. coli were classically enumerated using selective media (Beerens and Drigalski media under anaerobic and aerobic conditions, respectively). Total anaerobes were enumerated using the medium of Wilkins Chalgren in deep agar tubes. Microbial populations are given as percent of total culturable anaerobes.

\subsection{Human volunteers}

Human adults received unrestricted western-type diets and none received antibiotics or laxatives within 3 weeks prior to sampling. All volunteers gave informed consent to the research, which was approved by the local ethics committee.

\section{RESULTS AND DISCUSSION}

The present work demonstrates the use of quantitative dot-blot hybridisation using rRNA-targeted probes for the analysis of the structure of the human faecal microflora. It can be applied to frozen faecal samples.

\subsection{Structure of human faecal flora at the level of the domains}

Ribosomal RNA indices indicated that the Bacteria domain was always highly dominant. Bacterial rRNA represented $78.2 \pm 4.3 \%$ (range 59-94) of total $\mathrm{rRNA}$. It was the dominant hybridisation signal in all samples analysed. The archaeal and eucaryal rRNAs only showed a minor contribution to total RNA (0.28 and $2.02 \%$, respectively). The archaeal signal was considered representative of methanogenic populations, the only gut archaea described to date. Only six of ten samples showed a signal greater than $0.1 \%$ archaeal rRNA. For these samples, a Methanobacteriales-specific probe was further used to evaluate the proportion of this group, to which all current isolates of human faecal archaea belong. It represented $63.5 \pm 4.5 \%$ (range 43-77) of archaeal rRNA. This warrants further analysis using additive group probes covering 
the currently known diversity within methanogenic archaea, as performed for other ecosystems (Raskin et al., 1994). The eucaryal hybridisation signal is suspected to come from residual RNA from sloughed enterocytes. The added contribution of all three domains accounted for $80.5 \pm 4.5 \%$ (range $61-100$ ) of total rRNA. An aspecific signal for the universal probe would explain such observations. Furthermore, we have indications that the Bacteria and Eucarya domain probes, designed years ago with a limited sequence database derived from cultured microorganisms (Amann et al., 1990), are more specific than expected. This would also lead to an underestimation of the added contribution of all three domain probes to the universal signal. Besides, the two lowest results $(\sim 61 \%)$ corresponded to samples for which the RNA yields were the lowest $(<300 \mu \mathrm{g}$ total RNA/g faeces).

\subsection{Structure of the human faecal flora at the level of bacterial groups}

Two additive probes targeting the same region of $23 \mathrm{~S}$ rRNA (Roller et al., 1994), the one specific for high G + C Gram-positives (HGC) and the other for all other bacteria (NHGC), gave hybridisation intensities representing 1.4 and $80.6 \%$ of bacterial rRNA, respectively. The average sum of the corresponding signals was $82.0 \pm 8.4 \%$ (range $51-140$ ) of total bacterial rRNA. This very marked variation was due to measurements with the NHGC targeted probe. Besides, the signals obtained with a Bifidobacterium genus-specific probe (see later) were always greater than those obtained with the HGC probe, suggesting a systematic underestimation of HGC by the latter probe.

Total Bacteroides and enterics-group rRNAs accounted for $35.5 \pm 4.5 \%$ (range 22-61) and $2.7 \pm 0.7 \%$ (range 1.2-9.3) of bacterial rRNA, respectively. Low G + C Gram-positives (LGC), including the genera Streptococcus, Lactococcus, Enterococcus, Lactobacillus, Clostridium, Eubacterium, Ruminococcus and others, could only be accounted for by a broad group probe whose rRNA target has mismatches for some representatives of all concerned genera. It could therefore only give a partial measure of LGC. Their rRNA represented $24.2 \pm 5.5 \%$ (range 22-61) of bacterial rRNA based on this probe. Hence, using the currently available probe panel covering the genera Bacteroides and Bifidobacterium, and the enterics and LGC groups (latter, partial), two thirds of the bacterial rRNA could be attributed to identified phylogenetic groups (figure 2). Assuming that Bacteroides and enterics were the major Gramnegatives present, as expected from all microbial enumerations done so far, bacterial rRNA not accounted for by the probes used in this study may be essentially from LGCs. LGC would then account for 47 to $67 \%$ of bacterial rRNA. Alternatively, the fraction of the human faecal flora that has so far eluded cultivation could account for a significant part of the current discrepancy between the domain probe targeting a conserved region and group probes solely based on sequences derived from cultured organisms. This hypothesis could be investigated using several probes targeting other known Gram-negative gut anaerobes such as Fibrobacteriaceae for which a family-specific probe is available, or covering the proteobacteria for which former cultural characterisations indicated the presence of only gamma (enterics) and delta (sulphate-reducers) groups at or below $1 \%$ of total anaerobic bacteria. 


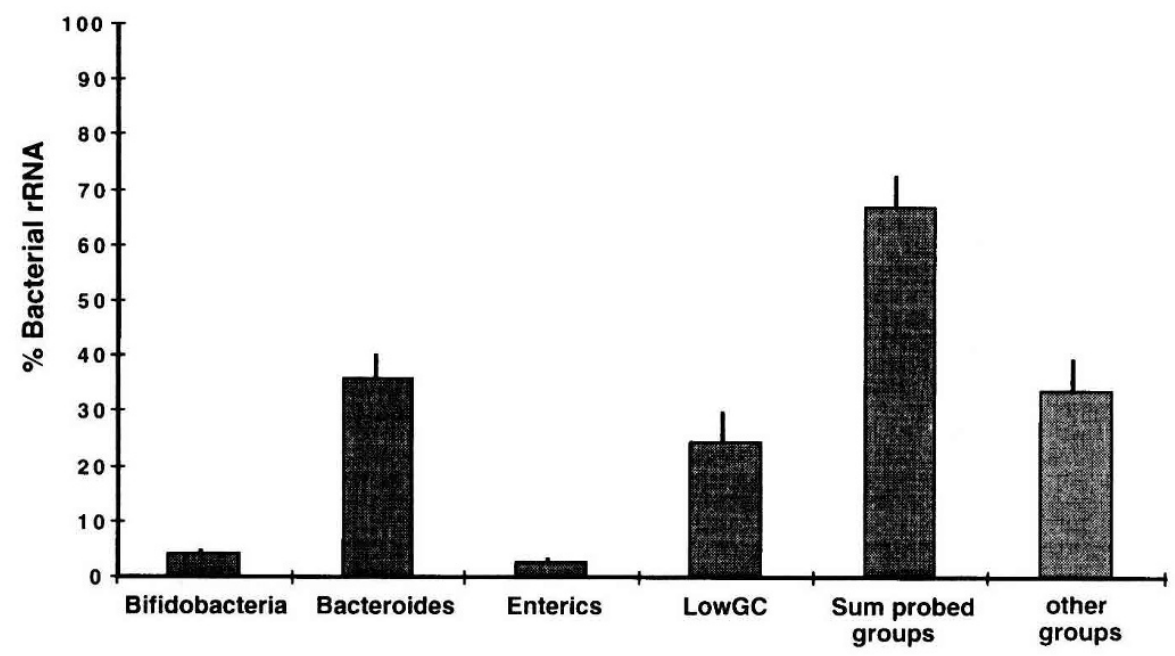

Figure 2. Ribosomal RNA indexes measured by quantitative dot-blot hybridisations using the Bacteria domain probe as reference and probes specific for the genus $B i$ fidobacterium, the Bacteroides-Porphyromonas-Prevotella cluster, the enterics group and the phylum of low $\mathrm{G}+\mathrm{C}$ Gram-positive bacteria (partial probe) (see table $I$ for probe sequence).

\subsection{Cultural counts versus relative rRNA abundance}

Cultural counts were more variable between individual faecal samples than were rRNA relative abundances for all three groups enumerated. Average counts of Bacteroides and Bifidobacterium, expressed as percent of total anaerobes, were two-fold higher than the corresponding rRNA indices (figure 3). This suggested a systematic overestimation of these genera using cultural techniques. This could be due to an underestimation of total anaerobes, a hypothesis supported by numerous examples of comparisons of total microscopic and cultural counts which indicate that only 10 to $90 \%$ of total observable microorganisms in situ are culturable (Moore and Holdeman, 1974; Finegold et al., 1983; Langendijk et al., 1995; Wilson and Blitchington, 1996).

We are currently performing a complete molecular inventory of human faecal flora based on sequencing of cloned $16 \mathrm{~S} \mathrm{rDNA}$, which will resolve certain ambiguities revealed by the hybridisation approach.

\section{ACKNOWLEDGEMENTS}

This work was funded in part by grants from the Bureau des Ressources Génétiques (BRG) and the EU FLAIR programme under project $\mathrm{n}^{\circ}$ CT97-3035. 


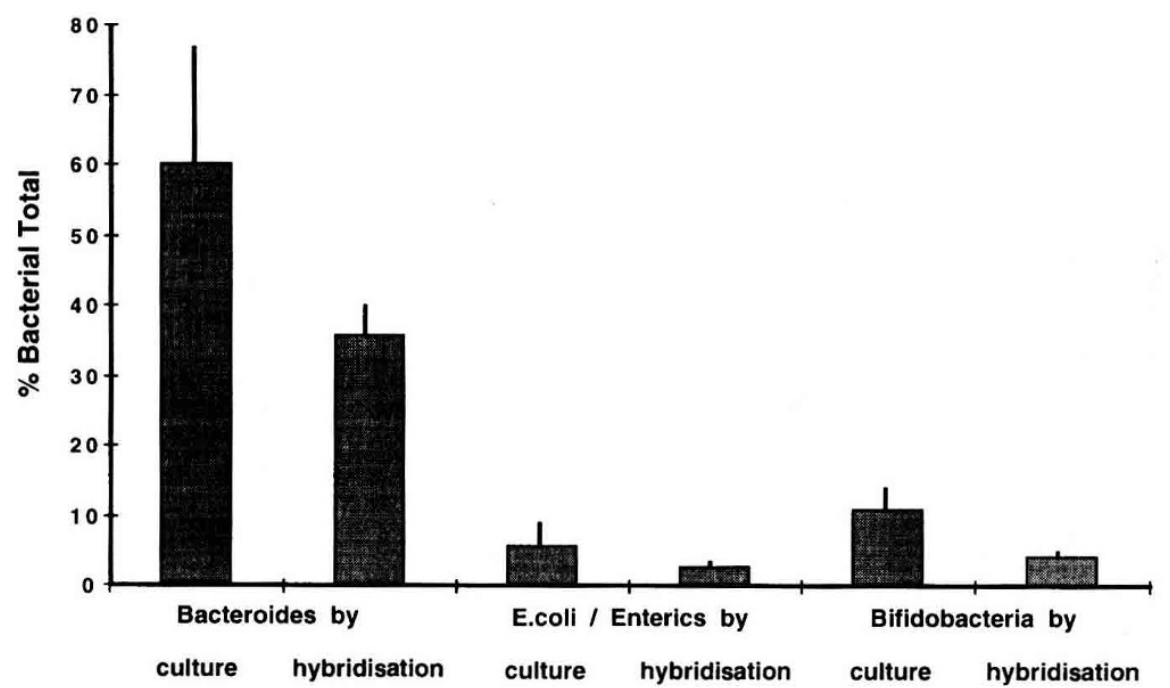

Figure 3. Comparison of ribosomal RNA indexes determined using quantitative dot-blot hybridisation (see figure 2 for details) and percent culturable bacterial groups determined using conventional anaerobic culture techniques, Wilkins Chalgren deep agar for total anaerobes and selective enumeration conditions for Bacteroides sp. (this study), E. coli (Drigalski medium) and Bifidobacterium sp. (Beerens medium).

\section{REFERENCES}

Alm E., Oerther D.B., Larsen N., Stahl D.A., Raskin L., The oligonucleotide probe database, Appl. Environ. Microb. 62 (1996) 3557-3559.

Amann R.I., Krumholz L., Stahl D.A., Fluorescent oligonucleotide probing of whole cells for determinative, phylogenetic, and environmental studies in microbiology, J. Bacteriol. 172 (1990) 762-770.

Conway P., Microbial ecology of the human large intestine, in: Gibson G.R., MacFarlane G.T. (Eds.), Human Colonic Bacteria: Role in Nutrition, Physiology, and Pathology, CRC Press, Ann Arbor, MI, 1995, pp. 1-24.

Corthier G., Muller M.C., Lharidon R., Selective enumeration of Bacteroides vulgatus and $B$. distasonis organisms in the predominant human fecal flora using monoclonal antibodies, Appl. Environ. Microb. 62 (1996) 735-738.

Doré J., Sghir A., Hannequart-Gramet G., Corthier G., Pochart P., Design and evaluation of a $16 \mathrm{~S}$ rRNA-targeted oligonucleotide probe for specific detection and quantitation of human faecal Bacteroides populations, Syst. Appl. Microbiol. 21, 1998, 65-71.

Finegold S.M., Sutter V.L., Mathisen G.E., Normal indigenous intestinal microflora, in: Hentges D.J. (Ed.), Human Intestinal Microflora in Health and Disease, Academic Press, New York, 1983, pp. 3-31.

Langendijk P., Schut F., Jansen G.J., Raangs G.C., Camphuis G.R., Wilkinson M.F., Welling G.W., Quantitative fluorescence in situ hybridization of Bifidobacterium spp. with genus-specific 16S rRNA-targeted probes and its application in fecal samples, Appl. Environ. Microb. 61 (1995) 3069-3075.

Mackie R.I., Doré J., Molecular ecology of gastrointestinal ecosystems, in: International Symposium on Microbial Ecology VII, Sao Paulo, Brazil, September 1995. 
Moore W.E.C., Holdeman L.V., Human fecal flora: the normal flora of 20 JapaneseHawaiians, Appl. Microbiol. 27 (1974) 961-979.

Olsen G.J., Woese C.R., Ribosomal RNA: a key to phylogeny, FASEB J. 7 (1993) 113-123.

Pace N.R., Stahl D.A., Lane D.J., Olsen G.J., Analyzing natural microbial populations by rRNA sequences, ASM News 51 (1985) 4-12.

Raskin L., Poulsen L.K., Noguera D.R., Rittmann B.E., Stahl D.A., Quantification of methanogenic groups in anaerobic biological reactors by oligonucleotide probe hybridization, Appl. Environ. Microb. 60 (1994) 1241-1248.

Roller C., Wagner M., Amann R., Ludwig W., Schleifer K.H., In situ probing of Gram-positive bacteria with high DNA G+C content using 23S rRNA-targeted oligonucleotides, Microbiology 140 (1994) 2849-2858.

Sayler G.S., Layton A.C., Environmental application of nucleic acid hybridization, Annu. Rev. Microbiol. 44 (1990) 625-648.

Stahl D.A., Comparison of nucleic acids from microorganisms: sequencing approaches. Molecular evolution: producing the biochemical data, Method. Enzymol. 224 (1993a) 373-391.

Stahl D.A., The natural history of microorganisms, ASM News 59 (1993b) 609613.

Stahl D.A., Amann R.I., Development and application of nucleic acid probes, in: Stackebrandt E., Goodfellow M. (Eds.), Nucleic Acid Techniques in Bacterial Systematics, John Wiley \& Sons, Chichester, UK, 1991, pp. 205-248.

Stahl D.A., Flesher B., Mansfield H.R., Montgomery L., Use of phylogenetically based hybridization probes for studies of ruminal microbial ecology, Appl. Environ. Microb. 54 (1988) 1079-1084.

Ward D.M., Molecular probes for analysis of microbial communities, in: Characklis W.G., Wilderer P.A. (Eds.), Structure and Function of Biofilms, John Wiley \& Sons, Inc., New York, 1989, pp. 145-163.

Ward D.M., Bateson M.M., Weller R., Ruff-Roberts A.L., Ribosomal RNA analysis of microorganisms as they occur in nature, Adv. Microb. Ecol. 12 (1992) 219-286.

Wilson K.H., Blitchington R.B., Human colonic biota studied by ribosomal DNA sequence analysis, Appl. Environ. Microb. 62 (1996) 2273-2278.

Woese C.R., Kandler O., Wheelis M.L., Towards a natural system of organisms: proposal for the domains Archaea, Bacteria, and Eucarya, Proc. Natl. Acad. Sci. USA 87 (1990) 4576-4579.

Zeng D., Alm E.W., Stahl D.A., Raskin L., Characterization of universal smallsubunit rRNA hybridization probes for quantitative molecular microbial ecology studies, Appl. Environ. Microb. 62 (1996) 4504-4513. 